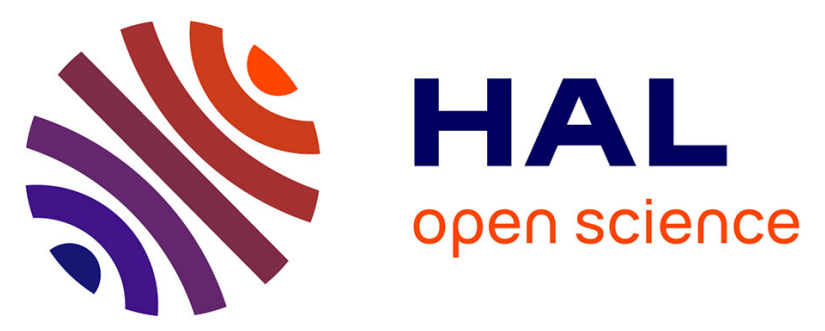

\title{
Photoisomerisation in Aminoazobenzene-Substituted Ruthenium(II) Tris(bipyridine) Complexes: Influence of the Conjugation Pathway.
}

\author{
Anissa Amar, Paul Savel, Huriye Akdas-Kilig, Claudine Katan, Hacène \\ Meghezzi, Abdou Boucekkine, Jean-Pierre Malval, Jean-Luc Fillaut
}

\section{To cite this version:}

Anissa Amar, Paul Savel, Huriye Akdas-Kilig, Claudine Katan, Hacène Meghezzi, et al.. Photoisomerisation in Aminoazobenzene-Substituted Ruthenium(II) Tris(bipyridine) Complexes: Influence of the Conjugation Pathway.. Chemistry - A European Journal, 2015, 21 (22), pp.8262-8270. 10.1002/chem.201406002 . hal-01142099

\section{HAL Id: hal-01142099}

\section{https://hal-univ-rennes1.archives-ouvertes.fr/hal-01142099}

Submitted on 9 Jun 2016

HAL is a multi-disciplinary open access archive for the deposit and dissemination of scientific research documents, whether they are published or not. The documents may come from teaching and research institutions in France or abroad, or from public or private research centers.
L'archive ouverte pluridisciplinaire $\mathbf{H A L}$, est destinée au dépôt et à la diffusion de documents scientifiques de niveau recherche, publiés ou non, émanant des établissements d'enseignement et de recherche français ou étrangers, des laboratoires publics ou privés. 


\section{Photoisomerization in Aminoazobenzene-Substituted \\ Ruthenium (II) tris(bipyridine) Complexes : \\ Influence of the Conjugation Pathway}

Dr. Anissa Amar ${ }^{\dagger}$, Dr. Paul Savel ${ }^{\dagger}$, Dr. Huriye Akdas-Kilig ${ }^{\dagger}$, Dr. Claudine Katan ${ }^{\dagger \star}$, Prof. Hacène Meghezzis, Prof. Abdou Boucekkine ${ }^{\dagger}$, Dr. Jean-Pierre Malval ${ }^{\ddagger \star}$, Dr. Jean-Luc Fillaut ${ }^{\dagger *}$.

† Institut des Sciences Chimiques de Rennes, UMR 6226 CNRS - Université de Rennes 1, Campus de Beaulieu, 35042 Rennes Cedex, France

$\S$ Laboratoire de Thermodynamique et Modélisation Moléculaire, USTHB, BP 32 EI Alia, 16111 Bab Ezzouar Alger, Algeria

‡ Institut de Science des Matériaux de Mulhouse, UMR CNRS 7361, Université de Haute-Alsace, 15, rue Jean Starcky, 68057 Mulhouse, France

e-mails:

claudine.katan@univ-rennes1.fr, $\quad$ jean-pierre.malval@uha.fr, jean-luc.fillaut@univ$\underline{\text { rennes } 1 . f r}$ 


\section{Abstract}

Transition metal complexes containing stimuli-responsive systems attract extensive attention for potential applications in optical devices, photonic memory, photosensing, as well as luminescence imaging. Among them, photochromic metal complexes offer the possibility to combine the specific properties of the metal centre and the optical response of the photochromic group. Here we report on the synthesis, the electrochemical properties and the photophysical characterization of a series of donor-acceptor azobenzene derivatives that possess bipyridine groups connected to a 4-dialkylaminoazobenzene moiety through various linkers. DFT and TD-DFT calculations are performed to complement experimental findings and contribute to their interpretation. Position and nature of the linker (ethynyl, triazolyl, none) are engineered and shown to induce different electronic coupling between donor and acceptor, in ligands and complexes. This in turn leads to strong modulations in terms of photoisomerization of the ligands and complexes. 


\section{Introduction}

Multi-mode photo-functional materials are currently attracting significant attention in relation with the emergence of molecular electronics. Light-driven real-time information-transmitting systems may be achieved by using photochromic switches ${ }^{[1]}$ and this issue raises growing interest in the field of materials chemistry. ${ }^{[2]}$ In particular, azobenzene derivatives are known to undergo efficient trans-to-cis isomerization upon irradiation with UV or blue light, which can be reversed either thermally or photochemically. ${ }^{[3]}$ Thanks to the simplicity of this moiety, the ease in molecular structure modification, their optical properties and photo-fatigue-resistance, azobenzene-based chromophores form a very attractive class of molecules. They are currently widely investigated for various applications. ${ }^{[3-4]}$ In order to develop azobenzene-based photoswitches that can exchange from the trans to the cis states under visible light, various strategies have been implemented. Among these, the most popular relies on the incorporation of electron-withdrawing or -donating substituents in the $\pi$-system of azo-chromophore, shifting the $\pi-\pi^{*}$ transition to the visible region. This route has already been explored in terms of dyes, polymers and materials processing methods. ${ }^{[5]}$ An alternative approach to red-shift the activation wavelength consists in gathering a transition metal group and an azobenzene moiety through a suitable linker. In this way, the specific properties of the metal centre and the optical response of the organic group are combined in a single entity. ${ }^{[6]}$ For instance, this has already been implemented by linking the azo unit to a polypyridine and coordinating the resulting ligand to a transition metal atom. ${ }^{[7]}$ Some of these complexes show photochromism ${ }^{[7 c]}$ or luminescence switching upon irradiation. ${ }^{[7 a, 8]}$ Even if the isomerization is assumed to take place from intraligand excited states 
localized on the azobenzene unit, the choice of the metal centre is known to drive the photochromic properties of the azobenzene unit. ${ }^{[7 c]}$ In fact, the photoisomerization was reported to be suppressed in azobenzene-containing polypyridine $R u(I I)$ complexes, presumably due to an energy transfer from the reactive azobenzenelocalized intraligand (IL) state to low-lying MLCT states. ${ }^{[9]}$ The location of the azobenzene unit in the bipyridine ligands was also established as an alternative way to influence the photochromic properties of the azobenzene unit in such complexes. ${ }^{[10]}$

In this paper, we report on the synthesis, the characterization and the photophysical properties of a series of azobenzene-containing bipyridines (L1-3) and their respective monometallic ruthenium complexes (Scheme 1). These ruthenium (II) heteroleptic complexes, $\mathrm{Ru}(\mathrm{bpy})_{2}\left(\mathbf{L 1}^{-3}\right)\left(\mathrm{PF}_{6}\right)_{2}$ (abbreviated as RuL1-3) differ by the nature of the azobenzene-containing bipyridine ligands $\mathbf{L}$ in which both the linker and its position were modified. L1 and L2 exhibit a donor/conjugated bridge/acceptor (D$\pi-A)$ structure, but difference stems from the position, nature and length of the conjugated bridge. While for L1 the azo unit is directly linked to position 4 of the bipyridine, it is linked to the bipyridine by an ethynyl bridge at position 5 in L2. L3 is similar to L2 except for the linker that contains a triazole moiety. The effect of the ligand types on the photophysical properties (absorption, emission and photoisomerization) of the ligands (L1-3) and complexes RuL1-3 are investigated experimentally and theoretically, and compared to the simple models L4 ${ }^{[11]}$ (Scheme 1) and $\mathrm{Ru}(\mathrm{bpy})_{3}\left(\mathrm{PF}_{6}\right)_{2}$. 


\section{Results and Discussion}

Synthesis. A specific strategy was considered for the synthesis of the azo-bipyridine ligand $\mathbf{L} \mathbf{1}$ which is different from compounds $\mathbf{L 2 - 3}$ as the azo unit is directly fixed to one of the pyridine cycles, in position 4 (Scheme 2; for experimental details, see SI). L1 was prepared via a Negishi cross-coupling reaction between the (E)-4-((2bromopyridin-4-yl)diazenyl)-N,N-dibutylaniline 2 and a pyridyl zinc reagent $\mathbf{4}$, obtained from the 2-bromopyridine $3^{[12]}$ (Scheme 2). The (E)-4-((2-bromopyridin-4yl)diazenyl)-N,N-dibutylaniline 2 was previously obtained in high yield (83\%), by reacting $\mathrm{N}, \mathrm{N}$-dibutyl aniline with the appropriate diazonium salt formed by the reaction of aqueous tetrafluoroboric acid ${ }^{[13]}$ with 4-amino-2-bromopyridine 1 . The second step consists of a lithium-halogen exchange by reaction of tert-butyllithium with 2-bromopyridine at $-78{ }^{\circ} \mathrm{C}$. After transmetallation to $\mathrm{Zn}$, a $\mathrm{CHCl}_{3}$ solution of $\mathrm{Pd}_{2}(\mathrm{dba})_{3}, t-B u_{3} \mathrm{PH} \cdot \mathrm{BF}_{4}$ and 2 were added, and the reaction was refluxed until completion. L1 was obtained in high yield (89\%) after aqueous workup in the presence of ethylenediaminetetraacetic acid (EDTA) and purification by column chromatography. The syntheses of the ligands L2-3, both substituted via an ethynyl (L2) or a triazolyl (L3) bridge in position 5 (Scheme 3), result from different catalysed reactions from 5-(ethynyl)-2,2'-bipyridine $5^{[14]}$ (Scheme 3). L2 was synthesized by the Pd-catalysed Sonogashira cross coupling reaction ${ }^{[15]}$ of 5 with 4 -(N,N-dibutylamino)4'-iodoazobenzene 6 , which was previously prepared by reaction of N,N-dibutylaniline with 4-iodobenzene diazonium chloride. L3 was obtained from $\mathbf{5}$ and $\mathbf{6}$, in the presence of sodium azide, via a Huisgen-type azide-alkyne cycloaddition ${ }^{[16]}$ to give the 1, 4-disubstituted 1, 2, 3-triazole ligand L3. The ${ }^{1} \mathrm{H}$ NMR signals for the bipyridine protons of L2 coincide with values reported for other 5'-monosubstituted 2,2'bipyridines. ${ }^{[12]}$ Shifts for the $\mathrm{H}^{4}$ and $\mathrm{H}^{6^{\prime}}$ of the pyridine linked to the triazolyl bridge, 
in L3, are significantly downfield shifted $\left[\mathrm{H}^{4}: 8.39\right.$ (L3) and 7.98 (L2); $\mathrm{H}^{6}: 9.20$ (L3) and $8.85 \mathrm{ppm}$ (L2) respectively], while the $\mathrm{CH}$ of the triazole is observed at $8.36 \mathrm{ppm}$, confirming the formation of $\mathbf{L} 3$. The $\mathrm{Ru}(\mathrm{bpy})_{2}(\mathbf{L} \mathbf{1 - 3})\left(\mathrm{PF}_{6}\right)_{2}$ complexes were prepared by the reaction of commercial cis-(bpy) ${ }_{2} \mathrm{RuCl}_{2} .2 \mathrm{H}_{2} \mathrm{O}$, in presence of one equivalent azo-bipyridine ligands L1-3, in refluxing ethanol/water (8:2). These complexes were obtained in good yields (72 to $89 \%$ ) after silica gel column chromatography, using a mixture of acetonitrile and saturated aqueous $\mathrm{KNO}_{3}$ as eluent, and were fully characterized by ${ }^{1} \mathrm{H}$ and ${ }^{13} \mathrm{C}$ NMR spectroscopy as well as Zabspec-TOF MS and elemental analysis.

Electrochemical Properties. Figure 1 shows typical cyclic voltammograms (CVs) of L1, RuL1 and Ru(bpy) $3^{2+}$ in acetonitrile (see also Figure S1). All the ligands globally display comparable electrochemical features (Table 1). The same holds true for their corresponding ruthenium-based complexes. A quasi-reversible oxidation process is clearly observed for the ligands which display a redox potential $\left(E_{o x}\right)$ in the $0.9-1.0$ $\mathrm{V}$ range. These values are slightly more positive than that of the $\mathrm{N}, \mathrm{N}^{\prime}$ dimethylaniline $\left(0.81 \mathrm{~V} v s\right.$. SCE $\left.{ }^{[17]}\right)$ due to the electron withdrawing character of the diazo $-\mathrm{N}=\mathrm{N}-$ group in para position, that should promote a better stabilization of the generated amine radical cation through an extended charge delocalization. The complexation with $\mathrm{Ru}^{2+}$ hardly affects the values of these redox potentials, which indicates a weak electronic interaction between the rims of each complex. This effect is also consistent with the quasi invariance of the second oxidation potential observed for all complexes assigned to the metal-centred oxidation. These potentials nicely match the values measured for $\mathrm{Ru}(\mathrm{bpy}) 3^{2+}$ (Figure 1). In the cathodic region, a reversible wave should

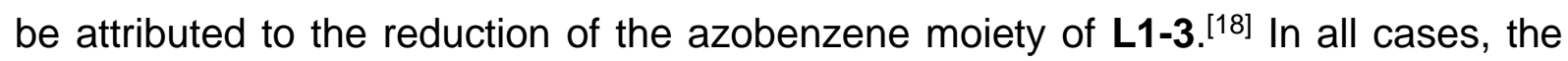


reduction potential is more positive than that of the 4-diethylamino-azobenzene ($1.57 \mathrm{~V} v$ s. SCE $\left.{ }^{[18 \mathrm{a}]}\right)$. Moreover, Ered shifts in the positive direction by about $0.15 \mathrm{~V}$ on going from L3 to L1. This suggests that the azobenzene moiety is sensitive to the electron withdrawing strength of its bipyridine-based substituent group. Interestingly, the presence of $\mathrm{Ru}^{2+}$ strongly amplifies this shift: the first reduction potential of RuL1 is about -0.95 vs. SCE as compared to a value of -1.29 vs. SCE for L1. Finally, all ruthenium-based complexes typically display three reversible ligand-centred (i.e. bipyridine) reduction waves at the low potential range. Even though such successive reduction processes occur at very close potential values, the measured half-wave potentials are globally comparable to those measured for $\mathrm{Ru}(\mathrm{bpy}) 3^{2+}$ (Table 1) , whereas the dialkylamino-azobenzene moieties, whose oxidation potential remains invariant, present a better reducibility with a noticeable increase of $E_{\text {red }}$ on going from RuL3 to RuL1. Such a change of the first reduction potential should presumably impact the relative position of the LUMO of the complexes (vide infra).

Photophysical Properties. The photophysical data of the compounds are gathered in Table 2. Figure 2 shows the absorption spectra of all chromophores in dichloromethane. In order to identify the position and the nature of the electronic transitions which are present within the longest wavelength absorption bands, DFT and TD-DFT calculations were carried out both for the ligands and their respective complexes.

All the ligands exhibit intense structureless bands in the blue visible region (Figure 2), with $\varepsilon$ MAX in the $28500-35000 \mathrm{M}^{-1} \mathrm{~cm}^{-1}$ range. TD-DFT calculations predict the presence of two low-lying $n \pi^{*}$ and $\pi \pi^{*}$ states and indicate that their energy gap is below $0.13 \mathrm{eV}$ for all ligands (Table 2). In particular, the TD-DFT results reveal that the symmetry forbidden $n \pi^{*}$ transition mainly arising from HOMO-2 $\rightarrow$ LUMO 
contributions lies close to the $\pi \pi^{*}$ one, for all three ligands L1-3. In other words, the observed structureless bands comprise two electronic transitions with distinctive symmetries: i) a $S_{0} \rightarrow S_{1}$ transition which has a very weak intensity due to its $n \pi^{*}$ nature ii) a $S_{0} \rightarrow S_{2}$ transition which is a strongly allowed $\pi \pi^{*}$ transition with a charge transfer (CT) character involving electronic delocalization all along the azobenzene backbone. ${ }^{[11,18 a, 19]}$ Due to the electron withdrawing ability of the bipyridine fragment which leads to a better energy stabilization of the $S_{0} \rightarrow{ }^{1} \pi \pi^{*}$ transition, the longest wavelength band of L2 is red-shifted by about $890 \mathrm{~cm}^{-1}$ as compared to L4 (Figure S2). The energy diagram of frontier orbitals (Figure 3 ) indicates that the $\pi \pi^{*}$ transition of L2 mainly corresponds to a HOMO-LUMO transition which exhibits a long range electronic delocalization all along the entire structure with a CT character from the aminoazobenzene to bipyridine moieties. Such CT character has been quantified by the amount of transferred charge $\left(\mathrm{q}^{\mathrm{CT}}\right)$ and the charge transfer distance $\left(\mathrm{d}^{\mathrm{CT}}\right)$ (Table S1). This is consistent with the fact that the $\pi \pi^{*}$ transition is strongly sensitive to $4,4^{\prime}$ azobenzene substitution effects and shifts to low energy region when increasing the strength of donor and/or acceptor ${ }^{[19-20]}$.

The same electronic feature can be observed for L1. The fact that the frontier orbitals are not localized on either the donor (amino) or acceptor (bipyridine) moieties is consistent with the idea that the conjugated azo bridge allows for effective conjugation within this ligand. On the other hand, L1, with the azobenzene group directly bonded to the 4 position, shows stronger absorption band, at low energy, than that observed for 4-phenylazopyridine $\left[310 \mathrm{~nm}\left(\varepsilon=23360 \mathrm{~L} \cdot \mathrm{mol}{ }^{-1} \cdot \mathrm{cm}^{-1}\right), 450 \mathrm{~nm}\right.$ $\left(\varepsilon=265\right.$ L.mol $\left.\left.{ }^{-1} \cdot \mathrm{cm}^{-1}\right)\right]^{[21]}$ in agreement with the expected greater push-pull character of $\mathbf{L} 1$. 
In the case of L3, the HOMO ( $\pi$-type) and LUMO ( $\pi^{*}$-type) are mainly localized on the photochromic part of the ligand with a very weak participation of the adjacent pyridine; such a disruption in the conjugation path should be presumably due to the presence of the triazole acting as a site-separating moiety. ${ }^{[22]}$ Interestingly, comparable $\mathrm{q}^{\mathrm{CT}}$ and $\mathrm{d}^{\mathrm{CT}}$ are maintained in L3 (Table S1).

Complexation with $\mathrm{Ru}^{2+}$ clearly enhances the electron withdrawing ability of the acceptor group (Figure S3). ${ }^{[23]}$ A stabilization of the $\pi \pi^{*}$ state due to a strong enhancement of its CT character is observed (Table 2). In turn, the longest wavelength absorption band observed for the free ligands shifts to the red region and increases in intensity upon complexation (Figure 2). Interestingly, bathochromic shift and hyperchromic effect both depend on the nature of the linker and on the positioning of the 2, 2'-bipyridine unit (i.e. position 4 vs. 5). A direct link of the bipyridine to the aminoazobenzene subunit (i.e. ligand L1) leads to the larger effects with a band red-shift by ca $4300 \mathrm{~cm}^{-1}$ and a 1.7-fold increase in intensity. Such important spectral changes contrast to those observed for RuL3 where the band hardly shifts by ca $90 \mathrm{~cm}^{-1}$ with a 1.2 -fold intensity increase. Finally, the absorption band of RuL2 displays an intermediate behavior with a bathochromic shift of ca 650 $\mathrm{cm}^{-1}$ and a 1.4-fold intensity increase. TD-DFT calculations reproduce with a good agreement such metal-induced spectral shifts $(\Delta \mathrm{E}<0.2 \mathrm{eV})$, even if the calculated $\mathrm{S}_{1}$ energy of RuL1 seems significantly overestimated (Table S2). In fact, a good correlation $\left(R^{2}>0.979\right)$ is obtained when plotting the theoretical bathochromic shifts of the complexes compared to their related ligands vs. those determined experimentally. The lowest-energy transition of RuL1 is dominated by a HOMO-LUMO ligand-centred transition (Figure S3) with a strong intramolecular CT character (Table S1) from the 4-dialkylaminoazobenzene to the 'fused' bipyridine chelating group. Interestingly, 
similar electronic effects are observed for the $\mathrm{S}_{0} \rightarrow \mathrm{S}_{1}$ transition of RuL2 which leads to a larger charge delocalization within the entire L2-subunit (Figure 4), leading to a dramatic increase of the charge transfer distance $d^{\mathrm{CT}}$ from 2.5 to $4.3 \AA$ (Table S1). However, in the case of RuL3, the $S_{0} \rightarrow S_{1}$ transition which displays a mixed $\pi \pi^{*}$ and $n \pi^{*}$ character is only localized on the 4-dialkylaminoazobenzene subunit (Figure 4). As for L3, this confirms that the triazole linker between the azobenzene and bipyridine units leads to a strong disruption of the electronic conjugation ${ }^{[22]}$. Moreover, our calculations exclude any metallic character within the lowest energy transition of RuL3 whereas a weak weighted contribution of the metal cation $(<5 \%)$ is noted within the LUMOs of RuL1 and RuL2. These findings suggest that the ruthenium tris(bipyridine) subunit is electronically decoupled with respect to its photochromic fragment. Such an assumption is also consistent with the unchanged redox properties of the metal complex site (vide supra). Moreover, similar electronic decoupling is suggested when comparing the absorption spectra of RuL1-3 with that of the $\mathrm{Ru}(\mathrm{bpy}) 3^{2+}$ model system (Figure 2). For RuL1-3, the high energy side of the spectrum (i.e. $<300 \mathrm{~nm}$ ) displays the same spectral feature than that observed for $\mathrm{Ru}(\mathrm{bpy}) 3^{2+}:$ i) a structured band at $240 \mathrm{~nm}$ corresponding to a first set of Metal-toLigand Charge Transfer (MLCT) transitions ${ }^{[24]}$ ii) a second intense band located at $290 \mathrm{~nm}$ which should be assigned to the ligand-centred (LC) transitions ${ }^{[24]}$ (bipyridine-centred transitions). The substitution effect on one of the three bipyridine ligands induces a slight decrease of the LC band with a larger effect for RuL3 (i.e. $20 \%$ decrease). The lowest-energy band of $\mathrm{Ru}(\mathrm{bpy}) 3^{2+}$ located at $455 \mathrm{~nm}$ corresponds to a second set of $\mathrm{S}_{0} \rightarrow{ }^{1} \mathrm{MLCT}$ transitions. This characteristic band is clearly observed at the blue edge of the charge transfer band of RuL1. However, on 
going from RuL2 to RuL3, the MLCT band is progressively masked due to a gradual overlap with the lowest-energy band which shifts to the blue region.

Figure 5 shows the phosphorescence and the excitation spectra of the complexes in glassy matrix of ethanol. According to the excitation spectra recorded at the maximum luminescence wavelength, the MLCT band is dominating the excitation spectrum and coincides to that of $\mathrm{Ru}(\mathrm{bpy}) 3^{2+}$. Therefore, the energy of the $\mathrm{S}_{0} \rightarrow$ ${ }^{1} \mathrm{MLCT}$ transitions remains invariant whatever the structural changes on complexes. It is worth noting that the lowest-energy band is not observed within the excitation spectrum of RuL1 and is hardly visible for the other complexes. This suggests that the efficiency of the intersystem crossing (ISC) toward the ${ }^{3} \mathrm{MLCT}$ state is much higher upon excitation to the high-energy ${ }^{1} \mathrm{MLCT}$ state as compared to an excitation to the ${ }^{1} \pi \pi^{*}$ one. This will have strong consequences on the photoisomerization properties of the complexes (vide infra). The phosphorescence spectra of all complexes are located in the same spectral range which yields to triplet energies of 2.15, 2.02 and $2.10 \mathrm{eV}$ for RuL1, RuL2 and RuL3, respectively. Moreover, their luminescence lifetimes are 11,10 and $8 \mu \mathrm{s}$, respectively, in agreement with that of $\mathrm{Ru}(\mathrm{bpy}) 3^{2+}\left(\sim 5 \mu \mathrm{s}^{[18 b, 24]}\right)$. The lowest triplet state is the ${ }^{3} \mathrm{MLCT}$ which would thus exclude any triplet-triplet energy transfer process from the excited ruthenium tris(bipyridine) subunit to the azo photochromic moiety.

Hence, coordination to $\mathrm{Ru}^{2+}$ clearly impacts the charge transfer character of the lowest-energy transitions which are mainly localized on the conjugated photochromic subunit (Figure 4, Table S1). Even though the metal coordination sphere globally maintains its electronic integrity, important changes will be observed in the efficiency of the photochromic switches. 
Photoisomerization Reaction and Mechanism. Table 3 reports the values of the trans $\rightarrow$ cis photoisomerization quantum yields for all the chromophores in various solvents as well as the rate constants of the thermal cis $\rightarrow$ trans isomerization reactions. Figure 6 illustrates the changes of the absorption spectra of L2 and its complex during the isomerization reactions. Considering the simulated UV-visible spectra of both trans and cis isomers (Figure S4) and corresponding data (Table S3), we can first tentatively assign experimental changes of absorption spectra occurring after the irradiation inducing partial conversion of trans to cis conformation. As expected, calculations indicate that the trans-cis isomerisation induces a slight redshift (ca $0.1 \mathrm{eV}$ ) and a significant increase of oscillator strength for the $\mathrm{n} \pi^{\star}$ transitions mainly located on the azobenzene moiety (Figure S5). Indeed, the cis L1-3 ligands exhibit their first bright low-energy transition at $445 \mathrm{~nm}, 479 \mathrm{~nm}$ and $467 \mathrm{~nm}$, respectively. For instance, changes in the UV-vis absorption spectrum of L2, which exhibits experimentally the best conversion ratio (Table 3 ), are qualitatively well explained by TD-DFT calculations. As can be seen from the observed spectrum of L2 under irradiation (Figure 6), the decrease of the intensity of the low-energy band indicates the partial conversion of the trans to the cis form. Simultaneously, the intensity of the absorption bands in the UV range increases upon irradiation. These experimental observations are consistent with our theoretical results, namely the decrease of the intensity of the calculated low-energy absorption band when going from trans to cis isomers (Figure S4). A weak increase is observed in the trans-cis energy differences for the simulated complexes RuL1-3 as compared to the ligands. The highest calculated trans-cis energy difference is found for RuL1. By contrast, the calculated trans-cis energy difference of RuL3 is almost comparable to the value obtained for the ligand (L3), indicating that the complexation with ruthenium should 
only slightly affect the thermodynamics of the trans-cis isomerism. This is a direct consequence of the site isolation character of the triazole moiety (vide infra).

Figure 6 shows that upon continuous irradiation at $436 \mathrm{~nm}$, the longest wavelength absorption band of the L2 strongly decreases concomitantly with the growth of new bands in the 270-375 $\mathrm{nm}$ range and above $490 \mathrm{~nm}$. Three isosbestic points are observed at $256 \mathrm{~nm}, 385 \mathrm{~nm}$ and $512 \mathrm{~nm}$. At the photostationary state, the intensity of the main absorption band collapsed by a factor $\sim 4$ while the low energy band of RuL2 only decreased by a factor 0.75 . For this complex, a slight increase of the absorption bands is also observed in the $270-380 \mathrm{~nm}$ range with the presence of an isosbestic point at $401 \mathrm{~nm}$. The trans-to-cis photoconversion yield is relatively high for $\mathbf{L 2}$ with a total conversion of ca $83 \%$ in methylcyclohexane $(\mathrm{MCH})$ which only decreases by a factor 1.2 in dichloromethane (DCM). For the other ligands, the nature of the solvent strongly influences the photoconversion efficiency, especially for L1 whose conversion yield drops from 69 to $0 \%$ on going from $\mathrm{MCH}$ to $\mathrm{DCM}$. In DCM the relative proportion of L2 cis isomers is divided by a factor $\sim 8$ with respect to that in $\mathrm{MCH}$ or THF. Such important changes globally parallel those observed for the rates of thermal cis-to-trans isomerization (Table 3). For instance, the rates of L1 and $\mathbf{L} 3$ vary over more than two orders of magnitude between $\mathrm{MCH}$ and $\mathrm{DCM}$.

For the ruthenium complexes, the trans-to-cis photoisomerization quantum yields (when measurable) are globally divided by a factor 2.5 with respect to those of the ligands. As previously indicated, the metal-induced stabilization of the ${ }^{1} \pi \pi^{*}(\mathrm{CT})$ promotes a $\pi \pi^{*}-n \pi^{*}$ state inversion (Table 2). The photoisomerization dynamics will be thereby strongly modified. For instance, the dramatic decrease of the $S_{1}$ state energy observed for RuL1 (Ru directly involved in the conjugation pathway) probably favours the internal conversion processes according to the energy gap law. 
Photoinduced intramolecular electron transfers (PeT) should be considered as minor deactivation channels for all the complexes. The free energy $\left(\Delta \mathrm{G}_{e T}\right)$ for such a PeT can be estimated from the Rehm-Weller equation ${ }^{[25]}: \quad \Delta \mathrm{G}_{e T}=\mathrm{E}_{o x}-\mathrm{E}_{r e d}-\mathrm{E}_{o 0}$ neglecting the Coulomb part of the stabilization energy. According to the redox properties of the complexes (Table 1) and estimating the singlet state energy ( $\left.\mathrm{E}_{00}\right)$ from the onset of the absorption CT band in DCM, $\Delta \mathrm{G}_{e T}$ is estimated to be close to 0 eV for RuL1 and RuL2 and becomes hardly negative for RuL3 $(-0.13 \mathrm{eV})$. Noteworthy, the irradiation of the complexes at $436 \mathrm{~nm}$ corresponds to a direct excitation into their ${ }^{1}$ MLCT states. This should open a new deactivation channel to the ${ }^{3} \mathrm{MLCT}$ state as confirmed by the phosphorescence fingerprints of the complexes (Figure 5). Indeed, the intersystem crossing to the triplet MLCT state occurs rapidly in less $\sim 300 f^{[26]}$ for $\mathrm{Ru}(\mathrm{bpy}) 3^{2+}$ and with a $\Phi_{I S C}$ close to unity. ${ }^{[24]}$ Interestingly, the phosphorescence properties of the complexes in deoxygenated THF are hardly affected by the trans-to-cis photoisomerization (see Figure S6). ${ }^{[9 c, 27]}$ This observation is in line with the fact that the lowest triplet state is the ${ }^{3}$ MLCT which excludes any triplet-triplet energy transfer to the azo photochromic moiety. This suggests that the significant decrease of $\Phi_{t \rightarrow c}$ observed for RuL1-3 presumably stems from this competing deactivation channel to the ${ }^{3} \mathrm{MLCT}$ state as depicted in Scheme 4. By contrast to other azobenzene-conjugated $\mathrm{Ru}^{2+}$ complexes where the photoisomerization properties are completely switched off, ${ }^{[28]}$ the photochromic part of RuL2 and RuL3 remains relatively photoactivable despite the competition of intersystem crossing. This indicates that both competing processes should exhibit comparable rate constants.

\section{Conclusion.}


The present results demonstrate the importance of the position and nature of the linker in azobenzene containing polypyridine systems and their effects on the electronic coupling between donor and acceptor, in both ligands and complexes. This in turn leads to strong modulations of the photoisomerization properties of these species. An efficient electronic communication along the whole molecular backbone with extended conjugation, which involves the $\mathrm{Ru}$ cation, disfavours the photoisomerization reaction. In addition, the very low activation barrier along the thermal cis $\rightarrow$ trans isomerization path prevents any photostationary cis / trans equilibrium at room temperature. By contrast, an extension of molecular backbone from the bipyridine to the azobenzene with an ethynyl or a triazolyl linker results in photoswitchable complexes where the electronic communication along the azo containing ligand is weakly influenced upon coordination. Thus, our approach allows to suggest a route to provide polypyridine $R u(I I)$ complexes where the specific properties of the metal centre and the optical response of the organic group can be gathered.

\section{Experimental Section}

General synthetic procedure for $\mathrm{Ru}(\mathrm{bpy})_{2}\left(\mathrm{~L}_{1-3}\right)\left(\mathrm{PF}_{6}\right)_{2}$ complexes. Cis-dichloro, bis-(2,2'-bipyridine)-Ruthenium(II) $\quad(0.1 \mathrm{mmol})$ and corresponding substituted bipyridine $\mathbf{L}(0.1 \mathrm{mmol})$ were dissolved in $10 \mathrm{~mL}$ of a deoxygenated mixture of ethanol/water (8:2) and heated at reflux for $3 \mathrm{~h}$. After this time the mixture was cooled down to room temperature, $30 \mathrm{~mL}$ of water and $10 \mathrm{~mL}$ of a $\mathrm{KPF}_{6}$ satured aqueous 
solution were added. The precipitate was filtered, washed with water and diethyl ether and the red solid was dried under vacuum.

$\mathbf{R u}\left(\mathrm{bpy}_{2}\right)_{2}\left(\mathrm{~L}_{1}\right)\left(\mathrm{PF}_{6}\right)_{2}$ (RuL1). The pure product was obtained after column chromatography $\left[\mathrm{SiO}_{2}, \mathrm{CH}_{3} \mathrm{CN} / \mathrm{H}_{2} \mathrm{O} /\right.$ sat. $\mathrm{KNO}_{3}$ (95:5:0.5)], as a red solid (97 mg, 89\%). ${ }^{1} \mathrm{H}$ NMR $\left(\mathrm{CD}_{2} \mathrm{Cl}_{2}, 400 \mathrm{MHz}\right): \delta=8.70(\mathrm{~s}, 1 \mathrm{H}), 8.55-8.45(\mathrm{~m}, 5 \mathrm{H}), 8.15-8.05(\mathrm{~m}$, 5H), $7.96(\mathrm{~d}, J=9.2 \mathrm{~Hz}, 2 \mathrm{H}), 7.84(\mathrm{~d}, J=5.4 \mathrm{~Hz}, 1 \mathrm{H}), 7.80-7.65(\mathrm{~m}, 6 \mathrm{H}), 7.55-7.45$ (m, 5H), $6.79(\mathrm{~d}, J=9.2 \mathrm{~Hz}, 2 \mathrm{H}), 3.47(\mathrm{~m}, 4 \mathrm{H}), 1.69(\mathrm{~m}, 4 \mathrm{H}), 1.44(\mathrm{~m}, 4 \mathrm{H}), 1.02 \mathrm{ppm}$ (t, $J=7.3 \mathrm{~Hz}, 6 \mathrm{H}) .{ }^{13} \mathrm{C}\left\{{ }^{1} \mathrm{H}\right\} \mathrm{NMR}\left(\mathrm{CD}_{2} \mathrm{Cl}_{2}, 100 \mathrm{MHz}\right): \delta=158.3,156.8,156.3,156.1$, $156.0,155.9,152.5,151.0,150.6,150.5,150.5,150.3,142.6,137.3,127.4,127.3$, 127.2, 123.6, 123.6, 123.5, 123.3, 119.4, 115.1, 111.0, 50.5, 28.7, 19.4, 12.9 ppm. MS (Zabspec-TOF): $\mathrm{m} / \mathrm{z}: 400.6425\left[\mathrm{M}^{++}\right], 946.2477\left[\mathrm{M}^{++}+P F_{6}\right]$; elemental analysis calcd (\%) for $\mathrm{C}_{44} \mathrm{H}_{45} \mathrm{~F}_{12} \mathrm{~N}_{9} \mathrm{P}_{2} \mathrm{Ru}, \mathrm{H}_{2} \mathrm{O}$ : C, 47.66; $\mathrm{H}, 4.27$; N, 11.37; found: C, 47.92; $\mathrm{H}$, 4.23; N, 11.43 .

$\mathbf{R u}(\mathbf{b p y})_{2}\left(\mathbf{L 2}_{2}\right)\left(\mathbf{P F}_{6}\right)_{2} \quad(\mathbf{R u L 2})$. The pure product was obtained after column chromatography $\left[\mathrm{SiO}_{2}, \mathrm{CH}_{3} \mathrm{CN} / \mathrm{H}_{2} \mathrm{O} /\right.$ sat. $\mathrm{KNO}_{3}(95: 5: 0.5)$ ], as a red solid (86 mg, 72\%). ${ }^{1} \mathrm{H}$ NMR $\left(\mathrm{CD}_{2} \mathrm{Cl}_{2}, 500 \mathrm{MHz}\right): \delta=8.55-8.45(\mathrm{~m}, 6 \mathrm{H}), 8.19(\mathrm{dd}, J=8.5,2 \mathrm{~Hz}$, 1H), 8.15-8.05 (m, 5H), $7.85(\mathrm{~d}, J=9.3 \mathrm{~Hz}, 2 \mathrm{H}), 7.82(\mathrm{~d}, J=8.6 \mathrm{~Hz}, 2 \mathrm{H}), 7.80-7.70$ (m, 6H), $7.60(\mathrm{~d}, J=8.6 \mathrm{~Hz}, 2 \mathrm{H}), 7.55-7.45(\mathrm{~m}, 6 \mathrm{H}), 6.74(\mathrm{~d}, J=9.3 \mathrm{~Hz}, 2 \mathrm{H}), 3.41(\mathrm{~m}$, 4H), $1.66(\mathrm{~m}, 4 \mathrm{H}), 1.42(\mathrm{~m}, 4 \mathrm{H}), 1.01 \mathrm{ppm}(\mathrm{t}, J=7.4 \mathrm{~Hz}, 6 \mathrm{H}) .{ }^{13} \mathrm{C}\left\{{ }^{1} \mathrm{H}\right\} \mathrm{NMR}\left(\mathrm{CD}_{2} \mathrm{Cl}_{2}\right.$, $125 \mathrm{MHz}): \delta=156.8,156.6,156.2,155.4,152.7,152.4,151.4,151.3,151.3,143.0$, $140.1,138.3,138.3,132.7,128.6,128.2,128.2,128.1,125.6,124.8,124.7,124.4$, $124.3,123.9,122.2,121.0,111.2,98.1,84.8,50.9,29.4,20.2,13.7$ ppm. MS (Zabspec-TOF): $\mathrm{m} / z: 450.6578\left[\mathrm{M}^{++}\right], 1046.2829\left[\mathrm{M}^{++}+\mathrm{PF}_{6}\right]$; elemental analysis calcd 
(\%) for $\mathrm{C}_{52} \mathrm{H}_{49} \mathrm{~N}_{9} \mathrm{~F}_{12} \mathrm{P} 2 \mathrm{Ru}, \mathrm{H}_{2} \mathrm{O}$ : C, $51.66 ; \mathrm{H}, 4.25 ; \mathrm{N}, 10.43$; found: $\mathrm{C}, 51.58 ; \mathrm{H}, 3.99$; N, 10.12 .

$\mathbf{R u}\left(\mathrm{bpyy}_{2}\left(\mathrm{~L}_{3}\right)\left(\mathrm{PF}_{6}\right)_{2}\right.$ (RuL3). The pure product was obtained after column chromatography $\left[\mathrm{SiO}_{2}, \mathrm{CH}_{3} \mathrm{CN} / \mathrm{H}_{2} \mathrm{O} /\right.$ sat. $\left.\mathrm{KNO}_{3}(95: 5: 0.5)\right]$ as a red solid (89 mg, $72 \%) .{ }^{1} \mathrm{H}$ NMR $\left(\mathrm{CD}_{2} \mathrm{Cl}_{2}, 400 \mathrm{MHz}\right): \delta=8.71(\mathrm{~s}, 1 \mathrm{H}), 8.60(\mathrm{~d}, J=8.3 \mathrm{~Hz}, 1 \mathrm{H}), 8.56(\mathrm{~d}$, $J=8.2 \mathrm{~Hz}, 1 \mathrm{H}), 8.52(\mathrm{~m}, 4 \mathrm{H}), 8.44(\mathrm{~d}, J=8.3 \mathrm{~Hz}, 1 \mathrm{H}), 8.32(\mathrm{~s}, 1 \mathrm{H}), 8.14(\mathrm{t}, J=8.2$ $\mathrm{Hz}, 1 \mathrm{H}), 8.08(\mathrm{~m}, 4 \mathrm{H}), 7.98(\mathrm{~d}, J=8.7 \mathrm{~Hz}, 2 \mathrm{H}), 7.92(\mathrm{~d}, J=9.0 \mathrm{~Hz}, 2 \mathrm{H}), 7.90(\mathrm{~m}, 1 \mathrm{H})$, $7.84(\mathrm{~m}, 1 \mathrm{H}), 7.83(\mathrm{~d}, J=8.7 \mathrm{~Hz}, 2 \mathrm{H}), 7.75(\mathrm{~m}, 3 \mathrm{H}), 7.49(\mathrm{~m}, 1 \mathrm{H}), 7.42(\mathrm{~m}, 4 \mathrm{H}), 6.81$ (d, $J=9.0 \mathrm{~Hz}, 2 \mathrm{H}), 3.47-3.38(\mathrm{~m}, 4 \mathrm{H}), 1.63(\mathrm{~m}, 4 \mathrm{H}), 1.40(\mathrm{~m}, 4 \mathrm{H}), 0.98 \mathrm{ppm}(\mathrm{t}, J=$ $7.3 \mathrm{~Hz}, 6 \mathrm{H}) .{ }^{13} \mathrm{C}\left\{{ }^{1} \mathrm{H}\right\} \mathrm{NMR}\left(\mathrm{CD}_{3} \mathrm{CN}, 400 \mathrm{MHz}\right): \delta=156.8,156.7,156.7,156.6,156.4$, 155.8, 152.9, 151.7, 151.6, 151.5, 151.4, 151.1, 147.4, 142.4, 142.3, 137.7, 137.6, 137.5, 137.5, 136.1, 133.5, 130.0, 127.3, 127.3, 127.3, 125.1, 124.3, 124.1, 124.0, 124.0, 124.0, 122.8, 121.1, 120.9, 111.0, 50.2, 28.8, 19.6, 12.9 ppm. MS (ZabspecTOF): $m / z: 466.6282\left[\mathrm{M}^{+}\right], 1078.2177\left[\mathrm{M}^{++}+\mathrm{PF}_{6}{ }^{-}\right]$; elemental analysis calcd (\%) for $\mathrm{C}_{52} \mathrm{H}_{50} \mathrm{~F}_{12} \mathrm{~N}_{12} \mathrm{P} 2 \mathrm{Ru}, \mathrm{H}_{2} \mathrm{O}: \mathrm{C}, 49.88 ; \mathrm{H}, 4.19 ; \mathrm{N}, 13.42$; found: $\mathrm{C}, 49.61 ; \mathrm{H}, 4.13 ; \mathrm{N}$, 13.58 .

More experimental and computational details are available in the Supporting Information.

\section{Acknowledgements}

P. Savel was supported by a MESR grant. This work was granted access to the HPC resources of CINES and of IDRIS under the allocations 2013-[x2013080649] made by GENCI (Grand Equipement National de Calcul Intensif). 


\section{References.}

[1] a) T. Kudernac, N. Katsonis, W. R. Browne and B. L. Feringa, J. Mater. Chem. 2009, 19, 7168-7177; b) M. Irie, Chem. Rev. 2000, 100, 1683-1684; c) J. A. Delaire and K. Nakatani, Chem. Rev. 2000, 100, 1817-1846; d) H. Dürr and H. E. BouasLaurent, Photochromism: Molecules and Systems: Molecules and Systems, Elsevier, Amsterdam, 1990.

[2] a) V. Balzani, M. Venturi and A. Credi, Molecular Devices And Machines: A Journey Into The Nanoworld, WILEY-VCH Verlag GmbH, Weinheim, 2003; b) B. L. Feringa and W. R. Browne, Molecular Switches, Wiley Online Library, 2001; c) P. G. Lacroix, I. Malfant, J. A. Real and V. Rodriguez, Eur. J. Inorg. Chem. 2013, 2013, 615-627; d) T. Ikeda and O. Tsutsumi, Science 1995, 268, 1873-1875; e) B. Seefeldt, R. Kasper, M. Beining, J. Mattay, J. Arden-Jacob, N. Kemnitzer, K. H. Drexhage, M. Heilemann and M. Sauer, Photochem. Photobiol. Sci. 2010, 9, 213-220; f) H. Sun, X. Tian, J. Autschbach, Y. Yuan, J. Sun, X. Liu, C. Chen and H. Cao, J. Mater. Chem. C 2013, 1, 5779-5790; g) B. Feringa, N. Koumura, R. V. Delden and M. T. Wiel, Appl. Phys. A 2002, 75, 301-308; h) M. Natali and S. Giordani, Chem. Soc. Rev. 2012, 41, 4010-4029; i) M. M. Russew and S. Hecht, Adv. Mater. 2010, 22, 3348-3360.

[3] H. D. Bandara and S. C. Burdette, Chem. Soc. Rev. 2012, 41, 1809-1825.

[4] a) V. Ferri, M. Elbing, G. Pace, M. D. Dickey, M. Zharnikov, P. Samorì, M. Mayor and M. A. Rampi, Angew. Chem. Int. Ed. 2008, 47, 3407-3409; b) M. R. Banghart, A. Mourot, D. L. Fortin, J. Z. Yao, R. H. Kramer and D. Trauner, Angew. Chem. Int. Ed. 2009, 48, 9097-9101; c) M. Yamada, M. Kondo, R. Miyasato, Y. Naka, J. Mamiya, M. Kinoshita, A. Shishido, Y. Yu, C. J. Barrett and T. Ikeda, J. Mater. Chem. 2009, 19, 60-62; d) F. Puntoriero, P. Ceroni, V. Balzani, G. Bergamini and F. Vögtle, J. Am. Chem. Soc. 2007, 129, 10714-10719; e) Q. Zhang and C. G. Bazuin, Macromolecules 2009, 42, 4775-4786; f) A. Khan and S. Hecht, Chem. Eur. J. 2006, 12, 4764-4774; g) M. Mathews and N. Tamaoki, J. Am. Chem. Soc. 2008, 130, 11409-11416.

[5] a) J. Gao, Y. He, F. Liu, X. Zhang, Z. Wang and X. Wang, Chem. Mat. 2007, 19, 3877-3881; b) C. Dohno, S.-N. Uno and K. Nakatani, J. Am. Chem. Soc. 2007, 129, 11898-11899; c) N. B. Holland, T. Hugel, G. Neuert, A. Cattani-Scholz, C. Renner, D. Oesterhelt, L. Moroder, M. Seitz and H. E. Gaub, Macromolecules 2003, 36, 20152023.

[6] a) H. Nishihara, Bull. Chem. Soc. Jpn. 2004, 77, 407-428; b) H. Nishihara, Coord. Chem. Rev. 2005, 249, 1468-1475; c) M. Akita, Organometallics 2011, 30, 43-51.

[7] a) T. Yutaka, I. Mori, M. Kurihara, J. Mizutani, N. Tamai, T. Kawai, M. Irie and H. Nishihara, Inorg. Chem. 2002, 41, 7143-7150; b) T. Yutaka, M. Kurihara, K. Kubo and H. Nishihara, Inorg. Chem. 2000, 39, 3438-3439; c) T. Yutaka, I. Mori, M. Kurihara, N. Tamai and H. Nishihara, Inorg. Chem. 2003, 42, 6306-6313; d) A. Bianchi, E. Delgado-Pinar, E. García-España, C. Giorgi and F. Pina, Coord. Chem. Rev. 2014, 260, 156-215.

[8] Y. Hasegawa, T. Nakagawa and T. Kawai, Coord. Chem. Rev. 2010, 254, 26432651.

[9] a) S. Kume and H. Nishihara in Metal-based Photoswitches Derived from Photoisomerization, Vol. 123 (Ed. V. W. Yam), Springer Berlin Heidelberg, 2007, 79112; b) S. Kume and H. Nishihara, Dalton Trans. 2008, 25, 3260-3271; c) T. Yutaka, I. Mori, M. Kurihara, J. Mizutani, N. Tamai, T. Kawai, M. Irie and H. Nishihara, Inorg. Chem. 2002, 41, 7143-7150. 
[10] a) J. Otsuki, N. Omokawa, K. Yoshiba, I. Yoshikawa, T. Akasaka, T. Suenobu, T. Takido, K. Araki and S. Fukuzumi, Inorg. Chem. 2003, 42, 3057-3066; b) J. Otsuki, I. Kurihara, A. Imai, Y. Hamada and N. Omokawa, Bull. Chem. Soc. Jpn. 2007, 80, 902-909.

[11] K. N. Gherab, R. Gatri, Z. Hank, B. Dick, R.-J. Kutta, R. Winter, J. Luc, B. Sahraoui and J.-L. Fillaut, J. Mater. Chem. 2010, 20, 2858-2864.

[12] S. A. Savage, A. P. Smith and C. L. Fraser, J. Org. Chem. 1998, 63, 1004810051.

[13] N. Peor, R. Sfez and S. Yitzchaik, J. Am. Chem. Soc. 2008, 130, 4158-4165.

[14] A. M. Soliman, D. Fortin, P. D. Harvey and E. Zysman-Colman, Chem. Commun. 2012, 48, 1120-1122.

[15] K. Sonogashira, J. Organomet. Chem. 2002, 653, 46-49.

[16] A. K. Feldman, B. Colasson and V. V. Fokin, Org. Lett. 2004, 6, 3897-3899.

[17] a) M. Jin, J.-P. Malval, D.-L. Versace, F. Morlet-Savary, H. Chaumeil, A. Defoin, X. Allonas and J.-P. Fouassier, Chem. Commun. 2008, 6540-6542; b) E. Lapin, I. Jurevičiūtè, R. Mažeikienè, G. Niaura and A. Malinauskas, Synt. Met. 2010, 160, 1843-1847; c) J. P. Malval, J. P. Morand, R. Lapouyade, W. Rettig, G. Jonusauskas, J. Oberlé, C. Trieflinger and J. Daub, Photochem. Photobio. Sci. 2004, 3, 939-948.

[18] a) P. Savarino, G. Viscardi, E. Barni, E. Montoneri and P. Quagliotto, Dyes Pigm. 1992, 20, 1-11; b) M. Montalti, A. Credi, L. Prodi and M. T. Gandolfi, Handbook of Photochemistry, Third Ed., CRC Press, Boca Raton, 2006.

[19] a) Y. Hirose, H. Yui and T. Sawada, J. Phys. Chem. A 2002, 106, 3067-3071; b) M. a. Poprawa-Smoluch, J. Baggerman, H. Zhang, H. P. A. Maas, L. De Cola and A. M. Brouwer, J. Phys. Chem. A 2006, 110, 11926-11937; c) S. G. Mayer, C. L. Thomsen, M. P. Philpott and P. J. Reid, Chem. Phys. Lett. 1999, 314, 246-254.

[20] M. Hagiri, N. Ichinose, C. Zhao, H. Horiuchi, H. Hiratsuka and T. Nakayama, Chem. Phys. Lett. 2004, 391, 297-301.

[21] V. W.-W. Yam, V. C.-Y. Lau and L.-X. Wu, J. Chem. Soc., Dalton Trans. 1998, 1461-1468.

[22] C. Katan, P. Savel, B. M. Wong, T. Roisnel, V. Dorcet, J.-L. Fillaut and D. Jacquemin, Phys. Chem. Chem. Phys. 2014, 16, 9064-9073.

[23] a) K. Rurack, Spectrochim. Acta A 2001, 57, 2161-2195; b) J. P. Malval, R. Lapouyade, J.-M. Leger and C. Jarry, Photochem. Photobiol. Sci. 2003, 2, 259-266; c) P. Savel, H. Akdas-Kilig, J.-P. Malval, A. Spangenberg, T. Roisnel and J.-L. Fillaut, J. Mater. Chem. C 2014, 2, 295-305; d) J. Guillon, P. Sonnet, J.-P. Malval, S. Massip, I. Gosse, J.-M. Léger, R. Lapouyade, J. Rochette, J.-P. Monti and C. Jarry, Supramol. Chem. 2002, 14, 437-451.

[24] A. Juris, V. Balzani, F. Barigelletti, S. Campagna, P. Belser and A. von Zelewsky, Coord. Chem. Rev. 1988, 84, 85-277.

[25] D. Rehm and A. Weller, Isr. J. Chem. 1970, 8, 259.

[26] a) J. K. McCusker, Acc. Chem.Res. 2003, 36, 876-887; b) S. Wallin, J. Davidsson, J. Modin and L. Hammarström, J. Phys. Chem. A 2005, 109, 4697-4704.

[27] a) M. Akita, Organometallics 2011, 30, 43-51; b) G. Pourrieux, F. Fagalde, I. Romero, X. Fontrodona, T. Parella and N. E. Katz, Inorg. Chem. 2010, 49, 40844091; c) V. W.-W. Yam, Y. Yang, J. Zhang, B. W.-K. Chu and N. Zhu, Organometallics 2001, 20, 4911-4918; d) C.-C. Ko and V. W.-W. Yam, J. Mater. Chem. 2010, 20, 2063-2070.

[28] a) T. Yutaka, M. Kurihara and H. Nishihara, Mol. Cryst. Liq. Cryst. 2000, 343, 193-198; b) T. Yutaka, I. Mori, M. Kurihara, J. Mizutani, K. Kubo, S. Furusho, K. Matsumura, N. Tamai and H. Nishihara, Inorg. Chem. 2001, 40, 4986-4995. 


\section{FIGURES AND TABLES CAPTIONS}

Scheme 1 Molecular structures of the metal complexes and corresponding ligands.

Scheme 2 Reaction scheme for the synthesis of $\mathbf{L 1}$.

Scheme 3 Reaction scheme for the synthesis of $\mathbf{L} 2$ and $\mathbf{L} 3$.

Scheme 4 Simplified photophysical schemes relative to D- $\pi$-A ligands and their metal complexes when excited into their $S_{2}\left(\pi \pi^{*}\right)$ and ${ }^{1}$ MLCT states, respectively.

Figure 1 Cyclic voltammograms of L1, RuL1 and $\mathbf{R u}(\mathrm{bpy}) 3^{2+} .2 \mathrm{PF}_{6}{ }^{-}(\mathrm{mM}$ range in acetonitrile $+\mathrm{NBu}_{4} \mathrm{PF}_{6}$ at $\left.0.1 \mathrm{M}\right) \cdot \mathrm{v}=200 \mathrm{mV} \mathrm{s}^{-1}$.

Figure 2 Absorption spectra of the free ligands and their respective $\mathrm{Ru}^{2+}$ complexes in dichloromethane (Dotted lines: absorption spectrum of RuL complexes; full lines: $L$ ligands; dash-dotted lines: $R u(b p y)^{2+}$, $2 \mathrm{PF}^{-}{ }^{-}$.

Figure 3 Frontier molecular orbitals (MO) diagrams of L1-3 ligands with main transitions.

Figure 4 Density differences plots $\left(\Delta \rho(r)=\rho^{S 1}(r)-\rho^{S 0}(r)\right)$ of RuL1-3 between $S_{1}$ So states (light/yellow colour $=$ increase; dark/blue colour $=$ decrease of electron density; isovalue $0.03 \mathrm{au}$ ).

Figure 5 Phosphorescence (squares) and excitation (circles) spectra of the complexes in glassy matrix of ethanol (77K). (Dash-dotted lines: phosphorescence and excitation spectra of $R u(b p y) 3^{2+}$ in the same conditions).

Figure 6 Evolution of the absorption spectra of L2 in MCH and RuL2 in THF during the isomerization reactions (i.e. $h v$ or $\Delta$ ), dotted lines: stationary states. Insets: (a) Plots of the maximum absorbance at $436 \mathrm{~nm}$ as function of the irradiation time (b) Plots of the maximum absorbance at $436 \mathrm{~nm}$ during the cis $\rightarrow$ trans thermal reaction (sample is kept in the dark). Least square fit using a simple first-order equation (i.e. $f(t)=A+B\left(1-e^{-k_{k, t} \cdot t}\right)$ with as $A, B$ and $k_{t h}$ as variables $)$.

Table 1 Redox potentials of the compounds in acetonitrile.

Table 2 Absorption properties of the compounds and corresponding TD-DFT data (solvent: dichloromethane).

Table 3 Isomerization properties of compounds in various solvents ( $\lambda_{\text {irr }}: 436$ $\mathrm{nm})$. 


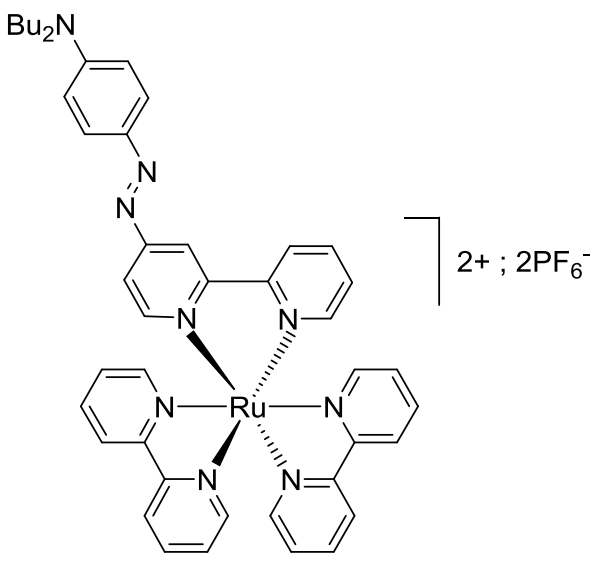

$\left[\mathrm{Ru}(\mathrm{bpy})_{2}(\mathrm{~L} 1)\right]^{2+} ; 2 \mathrm{PF}_{6}^{-}$

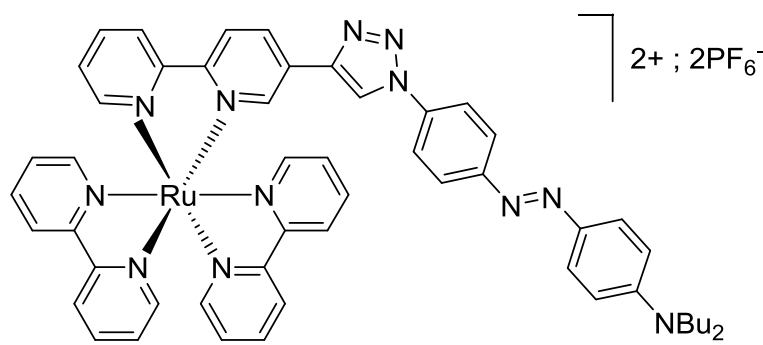

$\left[\mathrm{Ru}(\mathrm{bpy})_{2}(\mathrm{~L} 3)\right]^{2+} ; 2 \mathrm{PF}_{6}^{-}$

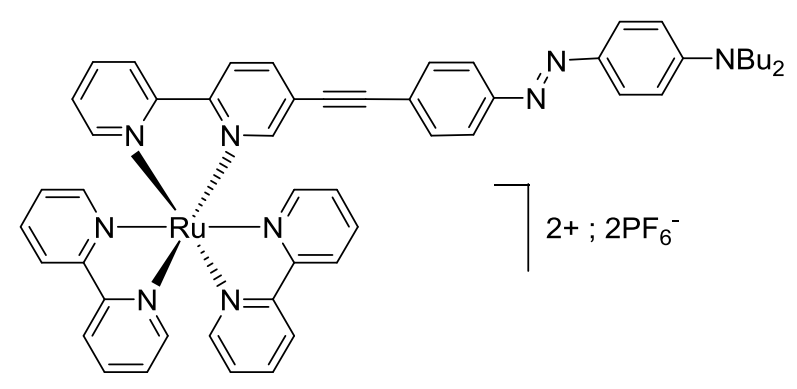

$\left[\mathrm{Ru}(\mathrm{bpy})_{2}(\mathrm{~L} 2)\right]^{2+} ; 2 \mathrm{PF}_{6}^{-}$



L4

\section{Scheme 1}




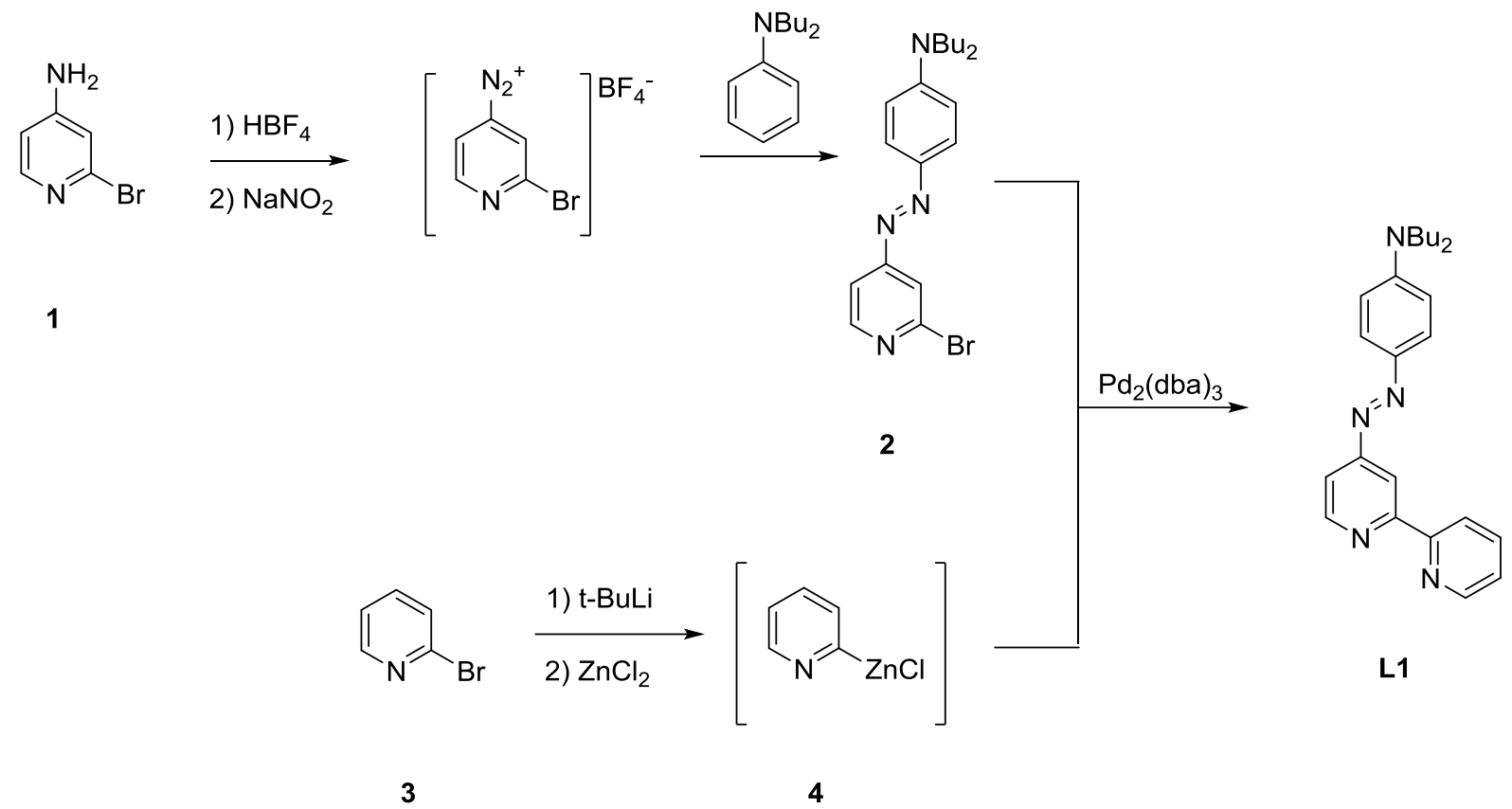

Scheme 2 


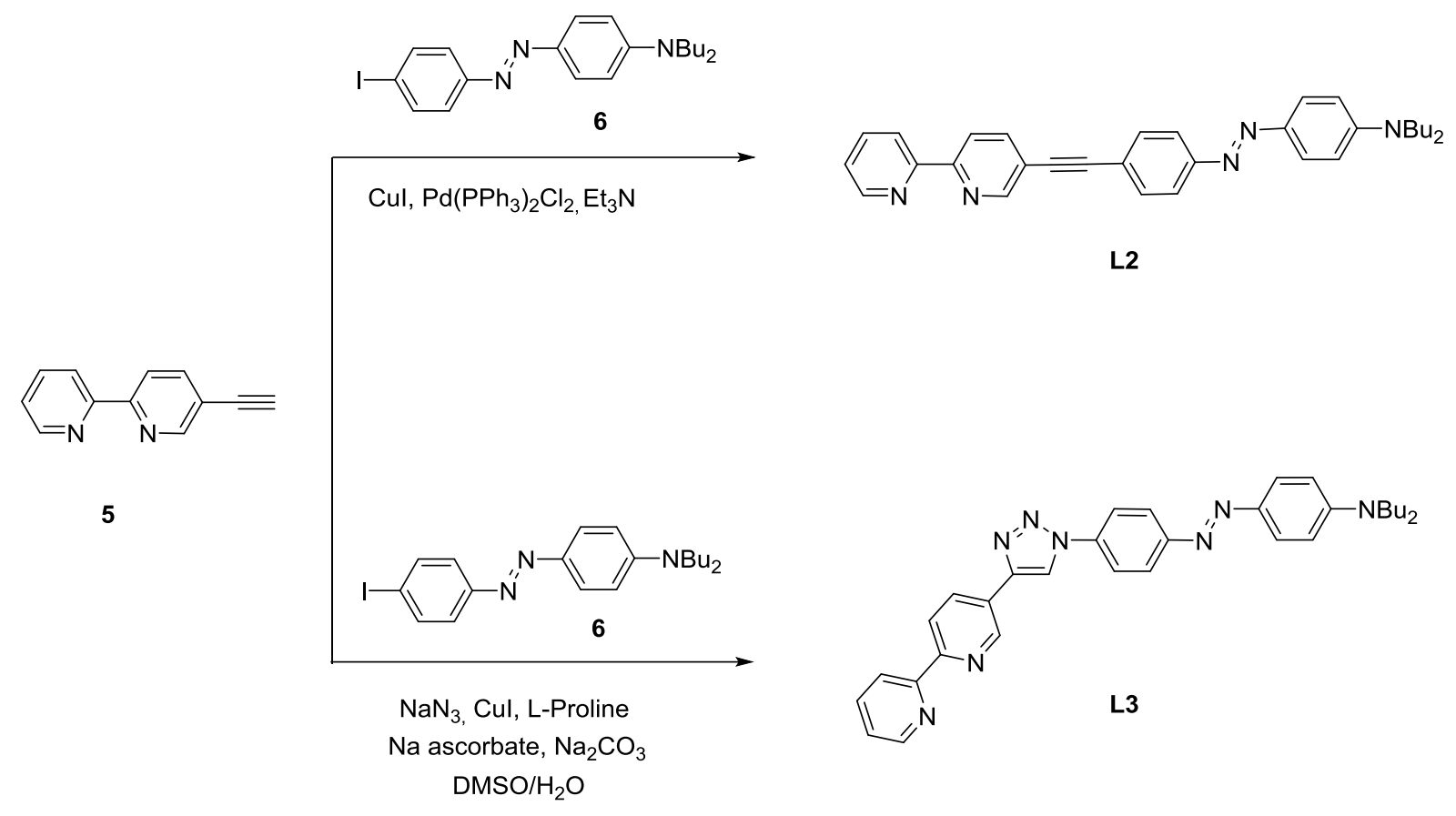

Scheme 3 




(Nu

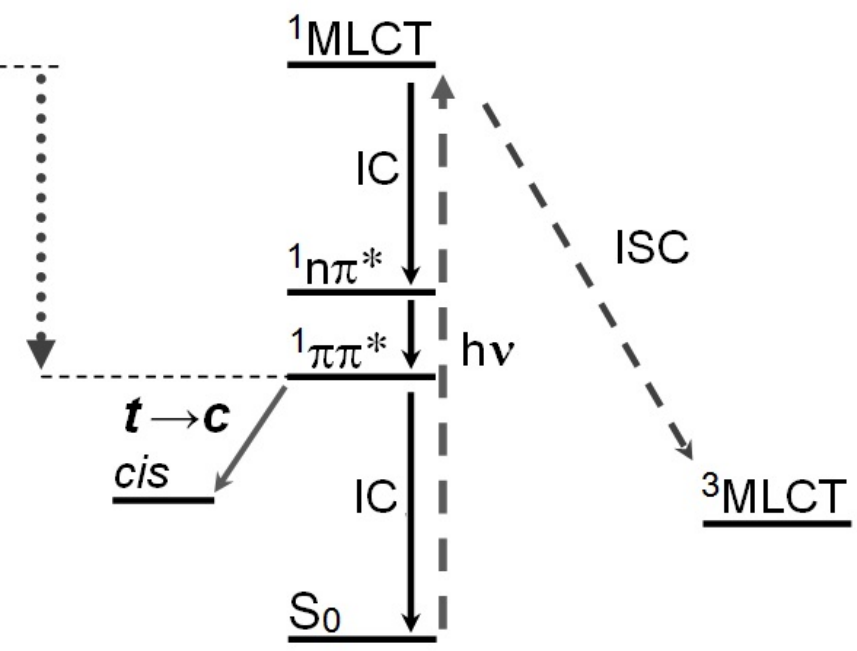

(Nu

Scheme 4 


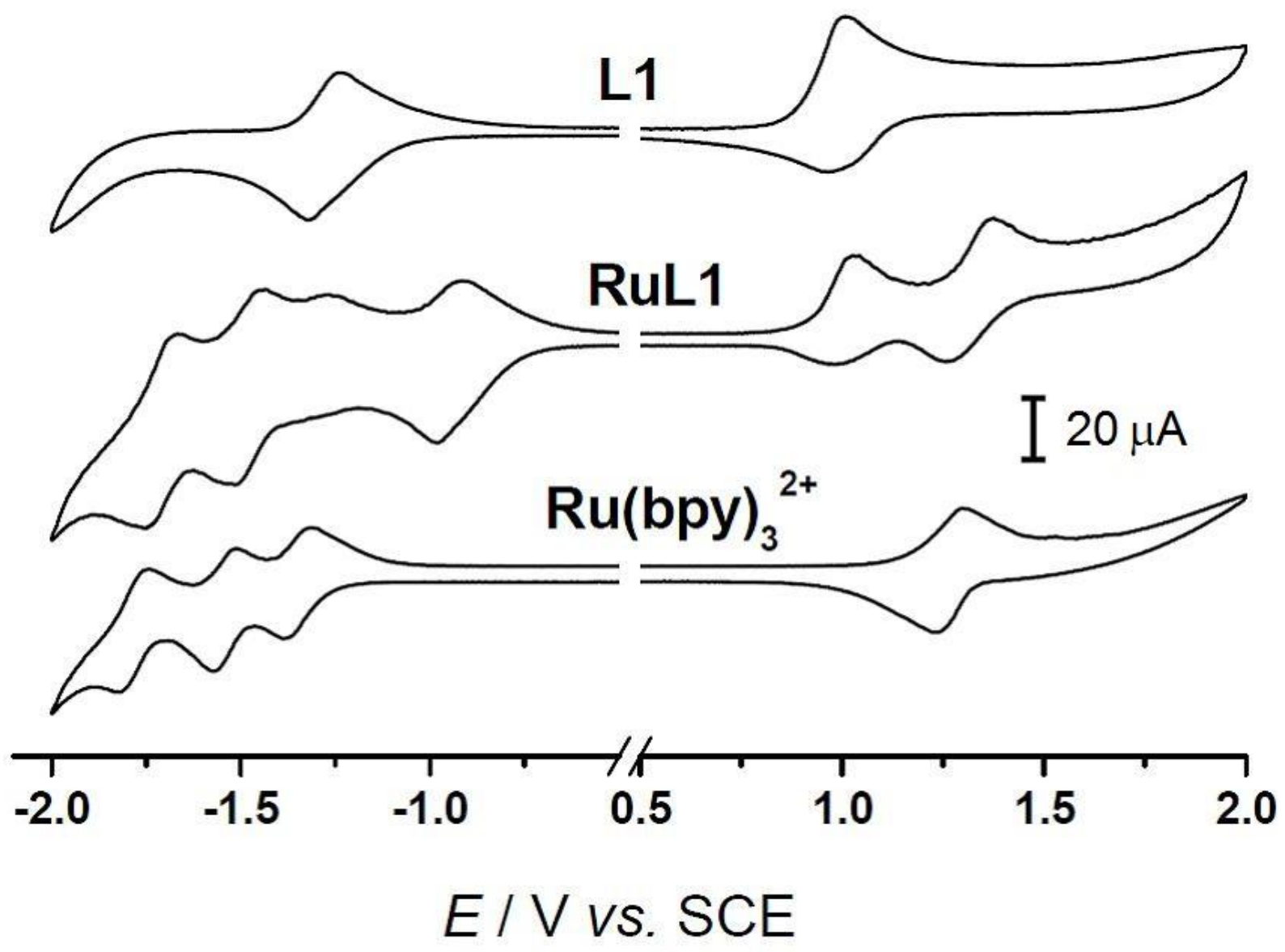

Figure 1 


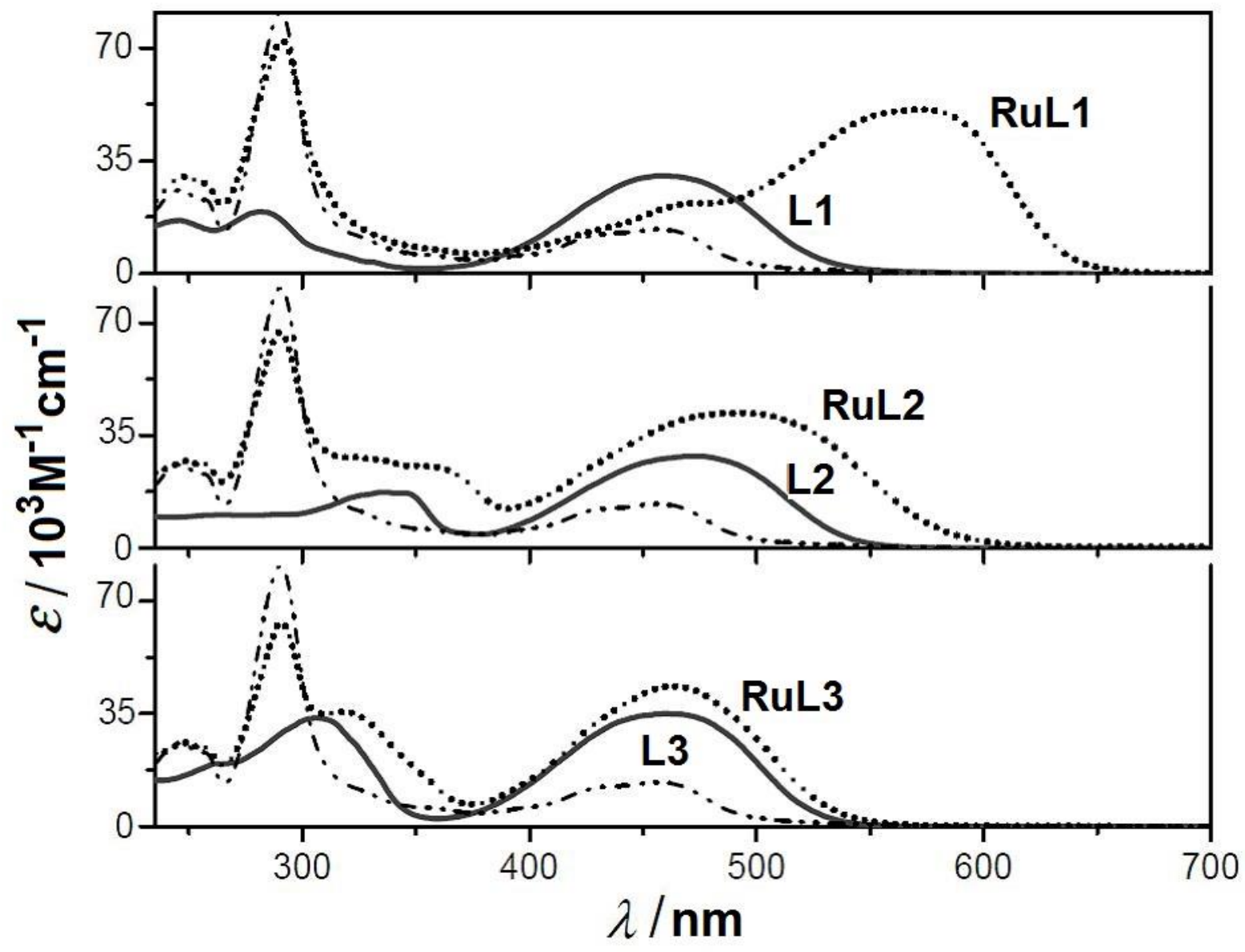

Figure 2 


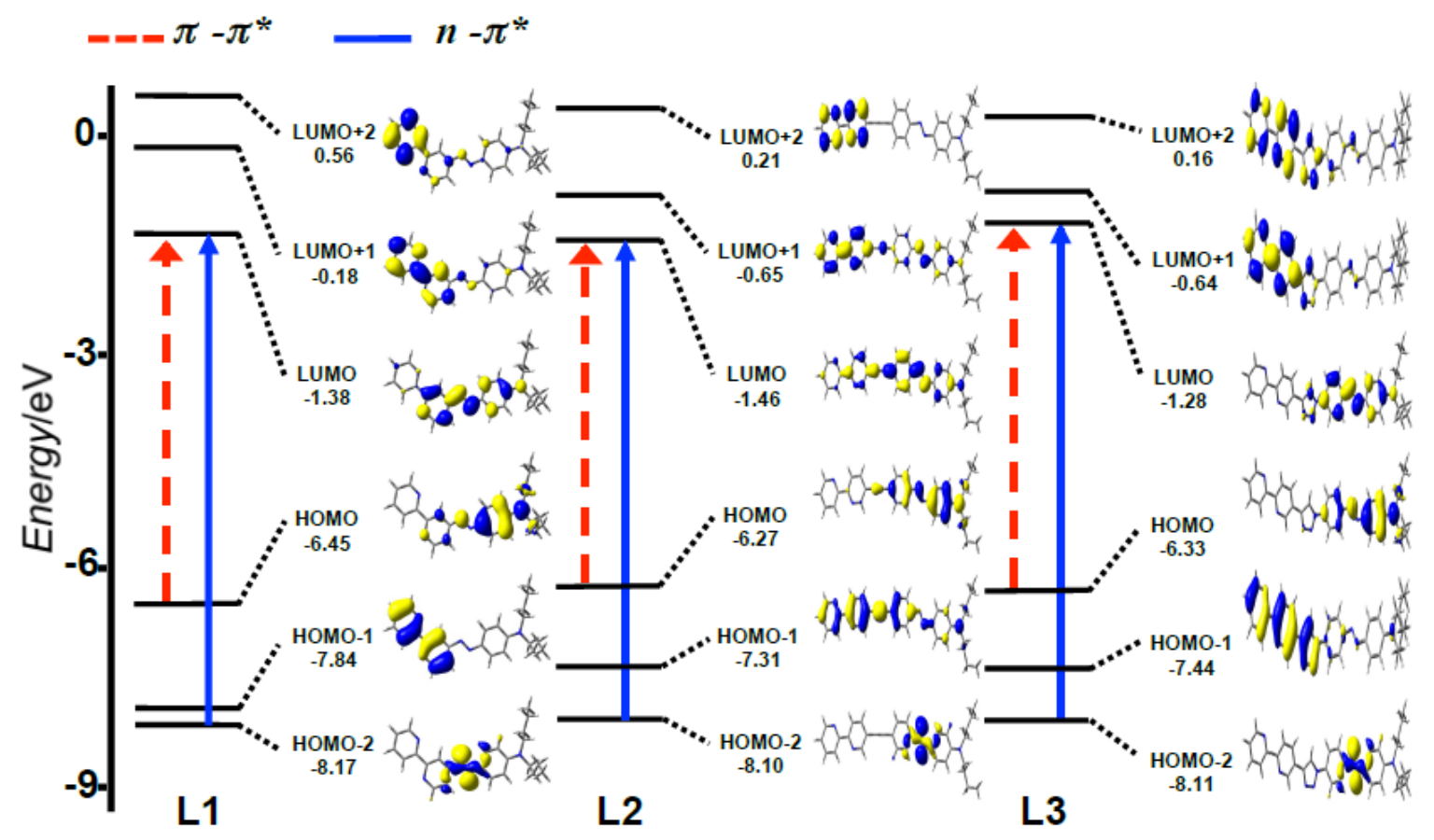

Figure 3 


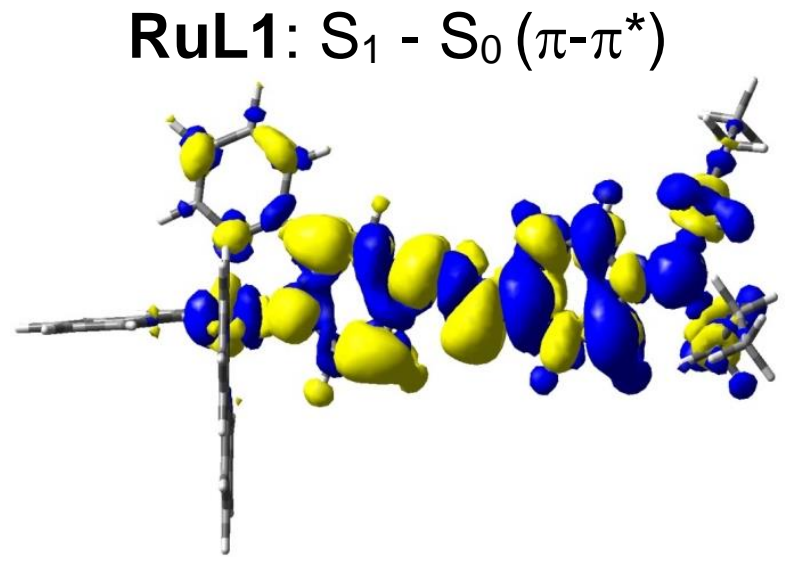

RuL2: $S_{1}-S_{0}\left(\pi-\pi^{*}\right)$

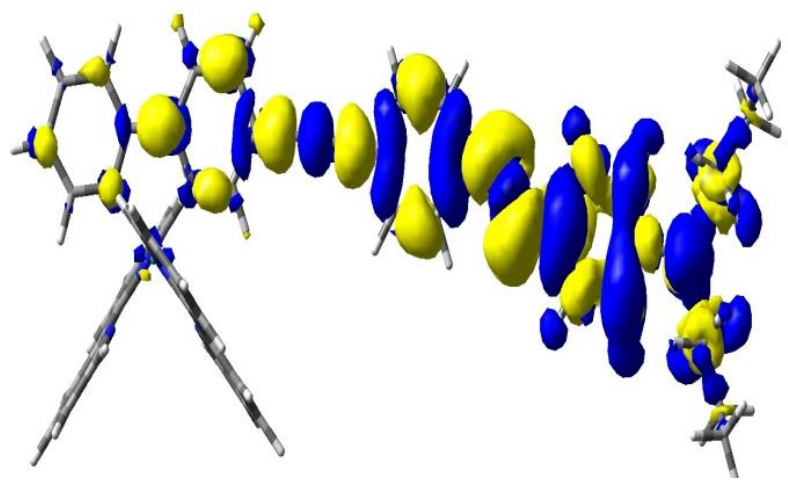

RuL3: $S_{1}-S_{0}\left(n-\pi^{*}+\pi-\pi^{*}\right)$

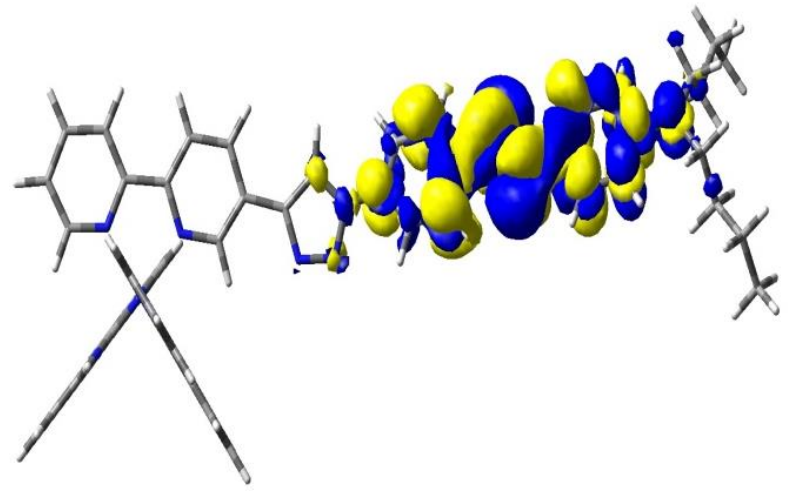

Figure 4 


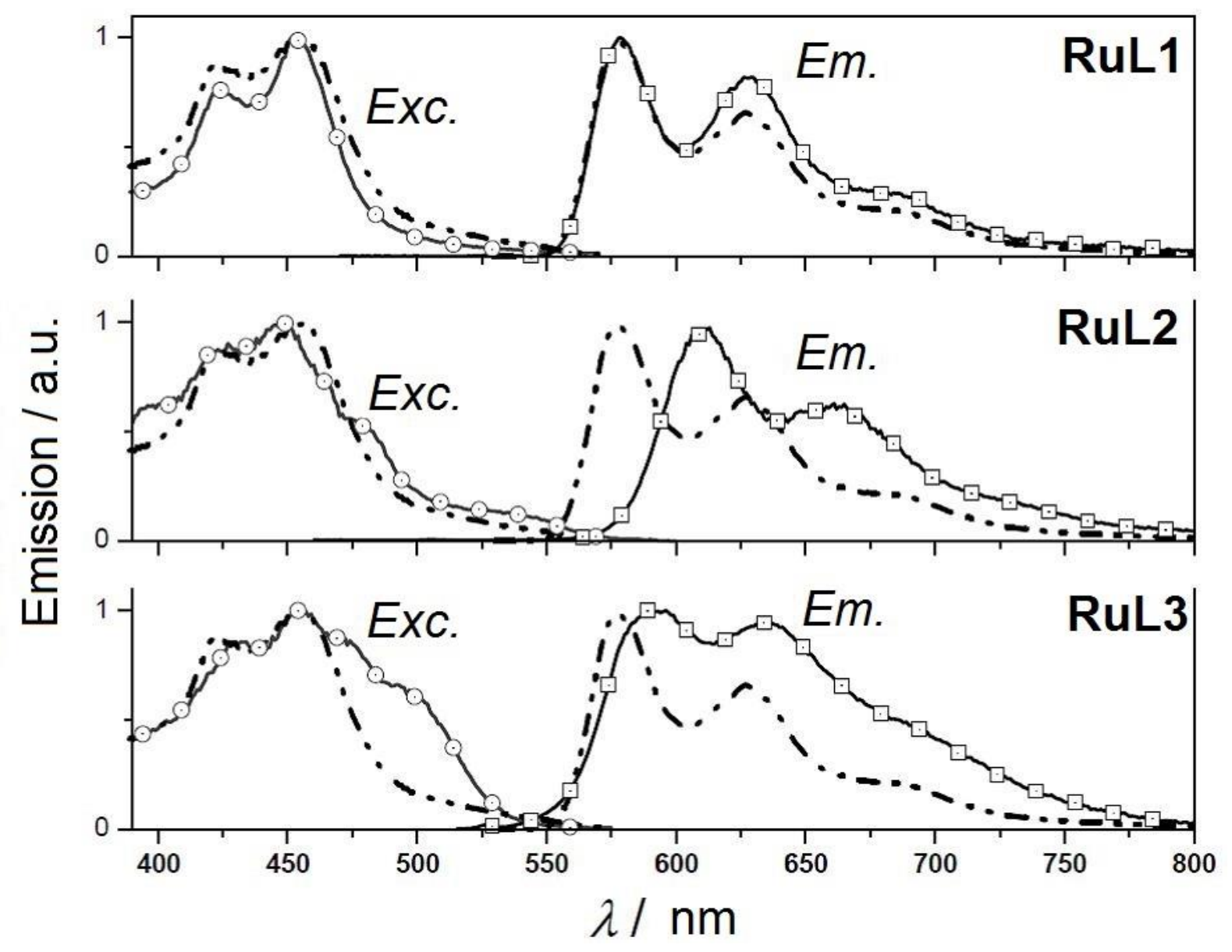

Figure 5 

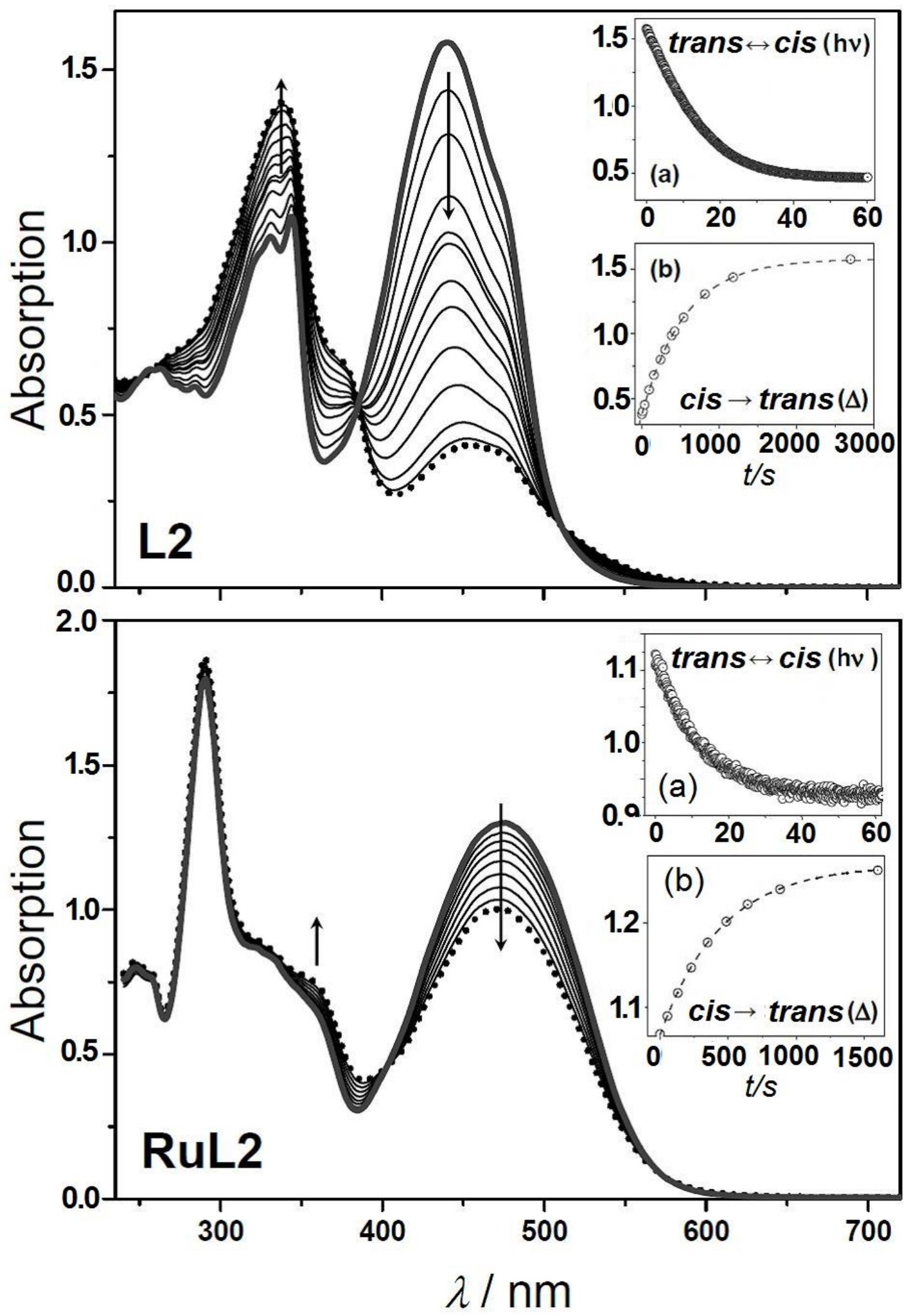

Figure 6 


\begin{tabular}{|c|c|c|}
\hline & $\begin{array}{c}E_{o x} / V \text { vs. } \\
\text { SCE }\end{array}$ & Ered / V vs. SCE \\
\hline L1 & 0.95 & -1.29 \\
\hline RuL1 & $1.00,1.34$ & $-0.95,-1.31,-1.49,-1.72$ \\
\hline L2 & 0.87 & $-1.39,-1.64$ (i) \\
\hline RuL2 & $0.88,1.33$ & $-1.19,-1.37,-1.51,-1.73$ \\
\hline L3 & 0.87 & -1.44 \\
\hline RuL3 & $0.89,1.29$ & $-1.19^{(i)},-1.29,-1.48,-1.74$ \\
\hline $\mathbf{R u}(\mathrm{bpy})_{3}{ }^{2+}$ & 1.27 & $-1.35,-1.54,-1.79$ \\
\hline
\end{tabular}

Table 1 
Experimental data

$$
\begin{gathered}
\lambda_{\text {abs }}(\varepsilon) \\
/ \mathrm{nm}\left(10^{3} \mathrm{M}^{-1} \mathrm{~cm}^{-1}\right)
\end{gathered}
$$

L1 278 (54.2), 459 (30.3)

RuL1 292 (72.3), 465 (21.3), 572 (50.9)

L2 343 (24.8), 472 (28.2)

RuL2 290 (67.3), 358 (25.3), 493 (42)

L3 303 (27.3), 460 (35.1)

RuL3 291 (63.4), 320 (35.5), 464 (43.5)

\section{Theoretical data} $\lambda_{a b s}\left(\mathrm{E}^{\text {th }}\right) \quad f \quad$ Type $\quad$ Main Transitions (fraction) $/ \mathrm{nm}$ $(\mathrm{eV})$

$\begin{array}{cccl}440 & 0.0 & n-\pi^{*} & \mathrm{H}_{-2} \rightarrow \mathrm{L}(0.91) \\ (2.81) & 1 & \pi-\pi^{*} & \mathrm{H} \rightarrow \mathrm{L}(0.93) \\ 421 & 1.3 & & \\ (2.94) & 8 & & \\ 471 & 1.7 & \pi-\pi^{*} & \mathrm{H} \rightarrow \mathrm{L}(0.90) \\ (2.63) & 5 & \mathrm{n}-\pi^{*} & \mathrm{H}_{-4} \rightarrow \mathrm{L}(0.83) \\ 446 & 0.0 & & \\ (2.78) & 0 & & \\ 447 & 2.2 & \pi-\pi^{*} & \mathrm{H} \rightarrow \mathrm{L}(0.85) \\ (2.77) & 7 & \mathrm{n}-\pi^{*} & \mathrm{H}_{-2} \rightarrow \mathrm{L}(0.73) \\ 435 & 0.0 & & \\ (2.85) & 2 & & \\ 465 & 2.3 & \pi-\pi^{*} & \mathrm{H} \rightarrow \mathrm{L}(0.57), \mathrm{H} \rightarrow \mathrm{L}_{+3} \\ (2.66) & 3 & \mathrm{n}-\pi^{*} & (0.30) \\ 439 & 0.0 & & \mathrm{H}_{-5} \rightarrow \mathrm{L}_{+3}(0.55), \mathrm{H}_{-5} \rightarrow \mathrm{L} \\ (2.82) & 0 & & (0.30) \\ 430 & 0.0 & \mathrm{n}-\pi^{*} & \mathrm{H}_{-2} \rightarrow \mathrm{L}(0.89) \\ (2.88) & 0 & \pi-\pi^{*} & \mathrm{H} \rightarrow \mathrm{L}(0.92) \\ 425 & 1.7 & & \\ (2.92) & 8 & & \\ 437 & 0.8 & \mathrm{n}-\pi^{*}+\pi-\pi^{*} & \mathrm{H}_{-5} \rightarrow \mathrm{L}_{+3}(0.42), \mathrm{H} \rightarrow \\ (2.84) & 0 & \mathrm{n}-\pi^{*}+ & \mathrm{L}_{+3}(0.34) \\ 424 & 1.0 & \pi-\pi^{*} & \mathrm{H} \rightarrow \mathrm{L}_{+3}(0.43), \mathrm{H}_{-5} \rightarrow \\ (2.92) & 7 & & \mathrm{~L}_{+3}(0.34)\end{array}$

\section{Table 2}




\begin{tabular}{|c|c|c|c|c|c|c|c|c|c|c|}
\hline & \multicolumn{5}{|l|}{ L1 } & \multicolumn{5}{|l|}{ RuL1 } \\
\hline & \multirow[b]{2}{*}{$\begin{array}{l}\lambda_{\text {abs }} \\
/ \mathrm{nm}\end{array}$} & \multicolumn{2}{|c|}{$\begin{array}{l}\text { Photochemical } \\
\text { isomerization }\end{array}$} & \multicolumn{2}{|c|}{$\begin{array}{c}\text { Thermal } \\
\text { isomerization }\end{array}$} & & \multicolumn{2}{|c|}{$\begin{array}{l}\text { Photochemical } \\
\text { isomerization }\end{array}$} & \multicolumn{2}{|c|}{$\begin{array}{c}\text { Thermal } \\
\text { isomerization }\end{array}$} \\
\hline & & $\Phi_{t \rightarrow c}$ & $\%$ cis & $\begin{array}{c}\mathrm{k}_{t h^{b}} \\
/ 10^{-3} \mathrm{~s}^{-} \\
1\end{array}$ & $\tau_{1 / 2}^{c}$ & $\begin{array}{l}\lambda_{a b s} \\
/ \mathrm{nm}\end{array}$ & $\Phi_{t \rightarrow c}$ & $\%$ cis & $\begin{array}{c}\mathrm{k}_{t h}{ }^{b} \\
/ 10^{-3} \mathrm{~s}^{-} \\
1\end{array}$ & $\begin{array}{c}\tau_{1 / 2}{ }^{c} \\
/ \mathrm{s}\end{array}$ \\
\hline $\mathrm{MCH}$ & 431 & 0.27 & 69 & 1.80 & 380 & $-d$ & & & & \\
\hline THF & 452 & - & 16 & 96.4 & 7 & 545 & $-a$ & 0 & & \\
\hline \multirow[t]{4}{*}{ DCM } & 459 & $-a$ & 0 & $-a$ & $-a$ & 571 & $-{ }^{a}$ & 0 & & \\
\hline & \multicolumn{5}{|l|}{ L2 } & RuL2 & \multirow{2}{*}{\multicolumn{2}{|c|}{$\begin{array}{c}\text { Photochemical } \\
\text { isomerization }\end{array}$}} & & \\
\hline & & $\begin{array}{l}\text { Photo } \\
\text { isome }\end{array}$ & $\begin{array}{l}\text { hemical } \\
\text { ization }\end{array}$ & $\begin{array}{l}\text { Ther } \\
\text { isomer }\end{array}$ & $\begin{array}{l}\text { nal } \\
\text { ation }\end{array}$ & & & & \multicolumn{2}{|c|}{$\begin{array}{c}\text { Thermal } \\
\text { isomerization }\end{array}$} \\
\hline & $\begin{array}{l}\lambda_{a b s} \\
/ \mathrm{nm}\end{array}$ & $\Phi_{t \rightarrow c}$ & $\%$ cis & $\begin{array}{c}\mathrm{k}_{t h^{b}}{ }^{-3} \\
/ 10^{-3} \mathrm{~s}^{-} \\
1\end{array}$ & $\tau_{1 / 2}^{c}$ & $\begin{array}{l}\lambda_{a b s} \\
/ \mathrm{nm}\end{array}$ & $\Phi_{t \rightarrow c}$ & $\%$ cis & $\begin{array}{c}\mathrm{k}_{t h}{ }^{b} \\
/ 10^{-3} \mathrm{~s}^{-} \\
1\end{array}$ & $\begin{array}{c}\tau_{1 / 2}{ }^{c} \\
/ \mathrm{S}\end{array}$ \\
\hline $\mathrm{MCH}$ & 439 & 0.50 & 83 & 1.82 & 385 & $-d$ & & & & \\
\hline THF & 462 & 0.46 & 73 & 0.80 & 870 & 474 & 0.19 & 28 & 2.20 & 315 \\
\hline \multirow[t]{4}{*}{ DCM } & 470 & 0.43 & 67 & 4.60 & 150 & 491 & $-{ }^{a}$ & 0 & & \\
\hline & \multicolumn{5}{|l|}{ L3 } & \multicolumn{5}{|l|}{ RuL3 } \\
\hline & & \multicolumn{2}{|c|}{$\begin{array}{l}\text { Photochemical } \\
\text { isomerization }\end{array}$} & \multicolumn{2}{|c|}{$\begin{array}{c}\text { Thermal } \\
\text { isomerization }\end{array}$} & & \multicolumn{2}{|c|}{$\begin{array}{c}\text { Photochemical } \\
\text { isomerization }\end{array}$} & \multicolumn{2}{|c|}{$\begin{array}{c}\text { Thermal } \\
\text { isomerization }\end{array}$} \\
\hline & $\begin{array}{l}\lambda_{a b s} \\
/ \mathrm{nm}\end{array}$ & $\Phi_{t \rightarrow c}$ & $\%$ cis & $\begin{array}{c}\mathrm{k}_{t h^{b}}{ }^{-3} \\
/ 10^{-3} \mathrm{~s}^{-} \\
1\end{array}$ & $\begin{array}{c}\tau_{1 / 2} c \\
/ \mathrm{s}\end{array}$ & $\begin{array}{l}\lambda_{a b s} \\
/ \mathrm{nm}\end{array}$ & $\Phi_{t \rightarrow c}$ & $\%$ cis & $\begin{array}{c}\mathrm{k}_{t h^{b}}{ }^{-3} \\
/ 10^{-3} \mathrm{~s}^{-} \\
1\end{array}$ & $\begin{array}{c}\tau_{1 / 2}{ }^{c} \\
/ \mathrm{s}\end{array}$ \\
\hline $\mathrm{MCH}$ & 436 & 0.31 & 70 & 0.32 & $\begin{array}{c}217 \\
0\end{array}$ & $-d$ & & & & \\
\hline THF & 448 & 0.34 & 72 & 0.19 & $\begin{array}{c}365 \\
0\end{array}$ & 456 & 0.14 & 25 & 0.52 & $\begin{array}{c}139 \\
0\end{array}$ \\
\hline DCM & 460 & - & 9 & 144.8 & 4.8 & 462 & - & 15 & 29.5 & 23.5 \\
\hline
\end{tabular}

Table 3 


\section{Graphical Abstract}

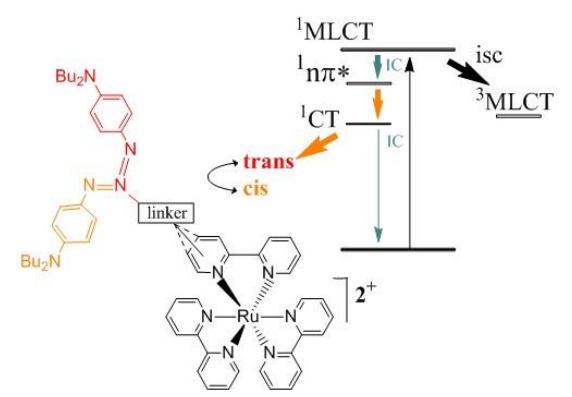




\section{Text for the Table of contents}

Engineering of azobenzene-containing bipyridine ligands leads to strong modulations of the photoisomerization properties of their ruthenium heteroleptic complexes: an electronic communication involving the ruthenium cation disfavours the photoisomerization; by contrast, extending the molecular backbone from the bipyridine to the azobenzene with ethynyl or triazolyl linkers results in photoswitchable complexes.

Short title if needed:

Photoswitchable azobenzene-ruthenium complexes 


\section{Keywords}

Photochromism; Azo compounds; Coordination chemistry; Ruthenium; Density functional calculations 